\title{
Pengaruh Independensi, Profesionalisme dan Role Stress Terhadap Kinerja Auditor BPK RI Perwakilan Provinsi Sulawesi Utara
}

\author{
SOFYAN TUBAGUS ${ }^{1}$, RIANE JOHNLY PIO ${ }^{2}$, WEHELMINA RUMAWAS ${ }^{3}$
}

\author{
1,2,3 Pengelolaan Sumber Daya Pembangunan, Minat Manajemen Perusahaan \\ Pascasarjana Universitas Sam Ratulangi
}

email: sofyan.tubagus@gmail.com¹, rianejpio@unsrat.ac.id² ${ }^{2}$ feibyrumawas@unsrat.ac.id²

\begin{abstract}
This research aims to know the influence of independence, professionalism and role stress on the performance of BPK RI auditors Regional Office For North Sulawesi Province. The sample size in this study is 63 respondents which is the total population of BPK RI auditor Regional Office for North Sulawesi Province. Method of analysis used is Structural Equation Modeling with Partial Least Squares approach (SEM-PLS). The results of this study show that as partially, independence has a positive effect on performance, as well as professionalism that positively affect the performance, while for variable role stress has a negative effect on performance. Furthermore, the simultaneous test found that independence, professionalism and role stress simultaneously affect to the performance. The results of this study also found that besides the independence and professionalism variables, the role stress variable has the most dominant influence, therefore it is always necessary to review and formulate the rules, policies and institutional strategies of BPK RI, especially at the Regional Office For North Sulawesi to suppress level of role stress for better auditor performance.
\end{abstract}

Keywords: Independency, Profesionalism, Role Stress, Performance

\begin{abstract}
Abstrak. Penelitian ini dilakukan dengan tujuan untuk menganalisis pengaruh independensi, profesionalisme dan role stress terhadap kinerja auditor BPK RI Perwakilan Provinsi Sulawesi Utara. Ukuran sampel dalam penelitian ini sebanyak 63 responden yang merupakan jumlah populasi keseluruhan dari auditor BPK RI Perwakilan Provinsi Sulawesi Utara yang ada. Metode analisis yang digunakan adalah Structural Equation Modeling dengan pendekatan Partial Least Squares (SEM-PLS). Hasil dari penelitian ini menunjukkan bahwa secara parsial independensi berpengaruh positif terhadap kinerja, begitu juga dengan profesionalisme yang berpengaruh positif terhadap kinerja, sedangkan untuk variabel role stress memiliki pengaruh negatif terhadap kinerja. Selanjutnya untuk pengujian simultan didapatkan independensi, profesionalisme dan role stress secara bersama-sama berpengaruh terhadap kinerja. Hasil dari penelitian ini juga menemukan bahwa disamping variabel independensi dan profesionalisme, variabel role stress adalah yang memiliki pengaruh paling dominan, untuk itu perlu selalu dilakukan pengkajian dan perumusan terhadap aturan, kebijakan maupun strategi kelembagaan dari BPK RI khususnya pada Perwakilan Provinsi Sulawesi Utara untuk bisa menekan tingkat role stress agar kinerja auditor semakin baik.
\end{abstract}

Kata kunci: Independensi, Profesionalisme, Role Stress, Kinerja

\section{Pendahuluan}

Pengelolaan keuangan negara merupakan salah satu aspek vital dalam bernegara, karena berkaitan erat dengan mampu dan tidaknya negara dalam mewujudkan tujuan dan cita-cita serta dalam menciptakan kesejahteraan. Lemahnya sistem pengelolaan keuangan negara dan sistem hukum di negara kita adalah pemicu tindakan penyalahgunaan kekayaan dan keuangan negara serta maraknya tindakan korupsi, kolusi dan nepotisme. Pengalaman bangsa Indonesia telah cukup membuktikan bahwa tindakan tersebut menyebabkan terpuruknya bangsa Indonesia dan sulitnya mewujudkan citacita bersama bangsa Indonesia. Pengelolaan keuangan negara memiliki tujuan untuk menjaga dan menjamin eksistensi negara serta untuk membiayai pengelolaan negara dalam mewujudkan kesejahteraan sesuai dengan amanat Undang Undang Nomor 17 Tahun 2003. Semuanya harus dikelola secara tertib, sesuai dan taat pada peraturan perundang-undangan. Agar segala kekurangan dalam laporan keuangan pemerintah dapat dideteksi secara akurat sebagai bahan dalam memperbaiki sistem pengelolaan dan tanggung jawab keuangan negara serta sebagai bahan dalam pengambilan kebijakan secara tepat maka diperlukan suatu lembaga khusus yang independen, objektif, dan tidak memihak dalam memeriksa laporan keuangan pemerintah. Lembaga yang dimaksud adalah Badan Pemeriksa Keuangan (BPK). 
Keberadaan BPK yang merupakan amanat UUD 1945 menunjukkan bahwa sejak awal, para pendiri Republik Indonesia sudah menyadari bahwa dalam rangka menegakkan pemerintahan yang bertanggung jawab, diperlukan sebuah Badan Pemeriksa Keuangan. Bahkan dalam amandemennya yang ditetapkan pada 10 November 2001 termuat ketetapan yang lebih tegas mengenai posisi BPKyang menyatakan bahwa BPK adalah badan yang "bebas dan mandiri" (Armando, 2012).

Usia 70 tahun bagi BPK tentu bukan waktu yang singkat. Tak heran bila selama kurun waktu itu, berbagai upaya telah dilakukan oleh BPK dalam meningkatkan kualitas pengelolaan keuangan negara yang transparan dan akuntabel. Hasilnya, tidak sedikit prestasi juga telah dilakukan oleh BPK. Tapi tidak sedikit pula persoalan yang dihadapi BPK. Cita-cita luhur yang ingin diwujudkan selalu memiliki tantangan dan rintangan, baik dari eksternal maupun internal, baik dari segi aturan, teknis dan tata cara, juga tantangan secara pribadi maupun kesatuan.

Dalam pantauan Indonesia Corruption Watch (ICW) sejak 2005 hingga Mei 2017, sedikitnya terdapat 6 kasus suap yang melibatkan 23 auditor/pejabat/staf BPK, dari 23 nama yang diduga terlibat, 5 orang telah divonis bersalah oleh Pengadilan Tipikor. Sebanyak 14 orang hanya dapat sanksi internal BPK, dan 4 di antaranya masih dalam proses pemeriksaan Komisi Pemberantasan Korupsi (kompas.com, 2017).

Rentetan kasus suap yang melibatkan oknum BPK yang terjadi mulai dari yang terkini yaitu kasus suap terhadap auditor Auditorat Utama Keuangan Negara III BPK RI oleh pejabat Kementerian Desa, Pembangunan Daerah Tertinggal dan Transmigrasi (Kemendesa PDTT), kemudian kasus suap terhadap auditor BPK Perwakilan Provinsi Jawa Barat oleh pejabat Pemerintah Kota Bekasi, hingga ke kasus suap auditor BPK Perwakilan Provinsi Sulawesi Utara oleh Walikota Tomohon merupakan hal yang sangat melemahkan kredibilitas BPK secara kesatuan.

BPK dalam menjalankan tugas dan fungsinya harus selalu memastikan bahwa proses pemeriksaan dan hasilnya dilakukan dengan memenuhi standar pemeriksaan. Selain itu juga memiliki nilai dan manfaat yang optimal bagi pemangku kepentingan lainnya. Bagi BPK, hasil pemeriksaan yang berkualitas, bermutu dan berdampak pada pengelolaan keuangan negara tidak terlepas dari independensi, profesionalisme dan komunikasi auditor BPK dalam melaksanakan tugas pemeriksaannya (BPK RI, 2016). Terkait persoalan independensi bahwa adanya kemungkinan dimana auditor akan melaporkan salah saji tergantung pada kualitas independensi auditor De Angelo (1981). Sejalan dengan hasil penelitian dari Arumsari et al. (2016) bahwa independensi auditor berpengaruh terhadap kinerja auditor. Selanjutnya pada persoalan kompetensi dan profesionalisme Guy et al. (2002) menjelaskan hubungan antara profesionalitas auditor dan kinerja auditor, bahwa dibutuhkan kompetensi dan pengalaman untuk dapat menyelesaikan pekerjaan-pekerjaan dalam auditing, kemudian secara empiris sejalan dengan hasil penelitian dari Novatiani et al. (2014) dan Nugraha et al. (2015) yang menyatakan profesionalisme auditor berpengaruh terhadap kinerja auditor.

Disadari bahwa dalam pelaksanaan tugasnya auditor selalu dihadapkan oleh potensi konflik peran (role conflict) maupun ketidakjelasan peran (role ambiguity) dalam dirinya. Efek potensial dari konflik peran dan ketidakjelasan peran sangatlah rawan, tidak hanya bagi individual dalam pengertian konsekuensi emosional seperti tekanan tinggi yang berhubungan dengan pekerjaan, kepuasan kerja, dan menurunnya kinerja, tetapi juga bagi organisasi dalam pengertian kualitas kinerja yang menjadi lebih rendah (Fanani et al., 2008). Kondisi ini terjadi karena kadangkala pihak entitas (klien) juga meminta "layanan" lain yang dimaksudkan untuk membuat seolah-olah kinerja keuangan perusahaannya terlihat baik. Disini timbul konflik antara tugas yang diemban oleh auditor dan permintaan yang disampaikan klien sehingga mempengaruhi kinerja auditor. Persoalan tekanan ekonomi misalnya membuat auditor tidak terlalu memperhatikan konflik peran, demi untuk mendapatkan klien dan kadang-kadang mereka mengorbankan etika profesional, sehingga dalam bekerja mereka cenderung berkompromi dengan motif ekonomi (Koo et al., 1997). Kahn et al. (1964) dengan teori perannya mengatakan bahwa, role stress yang berkepanjangan dapat memupuk ketidakpuasan kerja, mengikis kepercayaan diri, dan menghambat kinerja. Secara empiris, hasil penelitian yang dilakukan Rahmawati (2012) juga menunjukkan bahwa konflik peran dan ketidakjelasan peran berpengaruh terhadap kinerja auditor.

Dari uraian yang terungkap sebelumnya secara singkat dapat dikemukakan hubungan empiris antara konsep yang menjadi variabel dalam penelitian ini. Independensi dan kompetensi berpengaruh terhadap kualitas audit (Tjun Tjun et al., 2012). Independensi, profesionalisme dan etika profesi berpengaruh terhadap kinerja auditor (Oktavia, 2015). Independensi dan kompetensi berpengaruh terhadap kepuasan kerja dan kinerja auditor (Awaludin, 2013). Independensi, profesionalisme, struktur audit dan role stress berpengaruh terhadap kinerja auditor (Putra, 2012). Role stress berpengaruh 
terhadap kepuasan kerja (Amilin et al., 2008). Konflik peran dan stress kerja berpengaruh terhadap komitmen organisasi (Assegaf, 2005). Konflik peran dan ketidakjelasan peran berpengaruh terhadap kinerja auditor (Fanani, 2008).

Berdasarkan teori dan kajian empiris dibangunlah model penelitian seperti gambar di bawah ini:

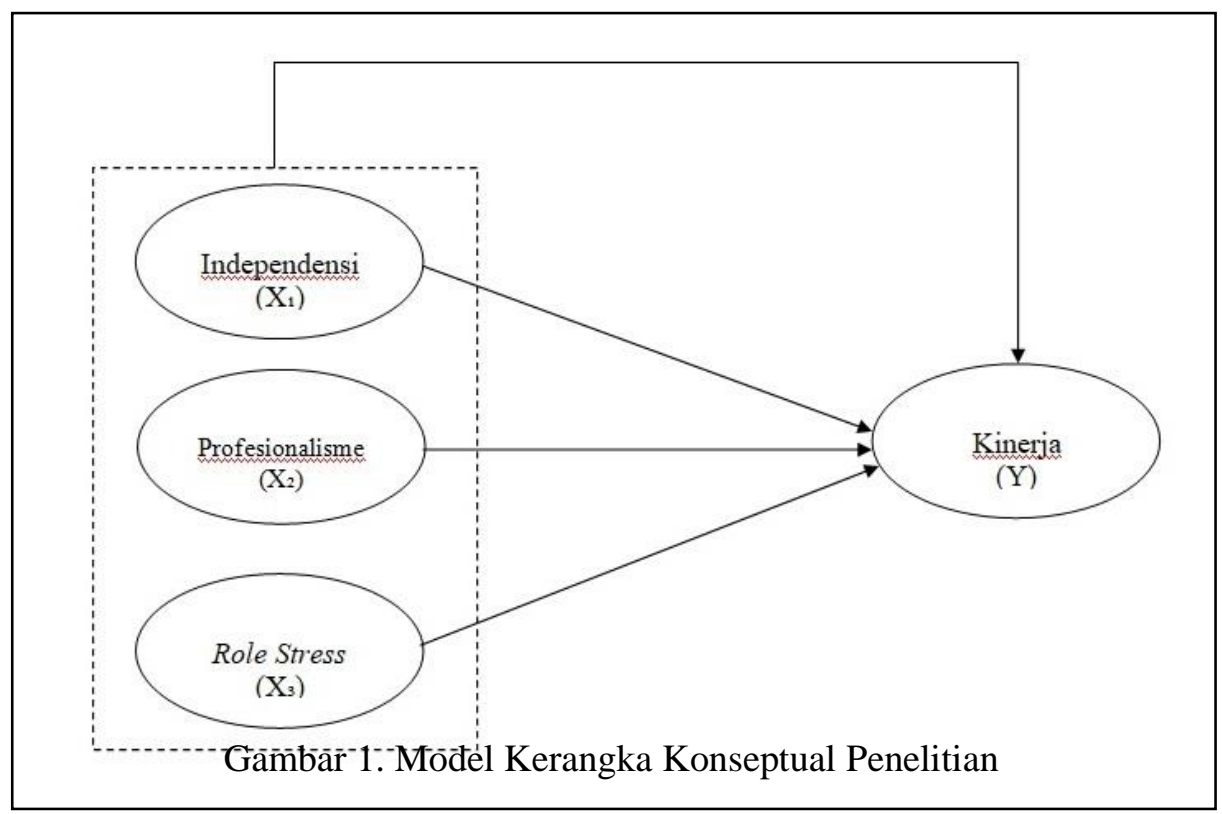

Hipotesis dalam penelitian ini dirumuskan sebagai berikut: (1) Terdapat pengaruh independensi terhadap kinerja auditor; (2) Terdapat pengaruh profesionalisme terhadap kinerja auditor; (3) Terdapat pengaruh role stress terhadap kinerja auditor; (4) Terdapat pengaruh independensi, profesionalisme dan role stress terhadap kinerja auditor.

\section{Metode Penelitian}

Penelitian ini merupakan penelitian eksplanatori (explanatory research), yakni menganalisis dan menjelaskan pengaruh antar variabel yang ada di dalam model penelitian ini dan bertujuan untuk menguji suatu teori atau hipotesis guna memperkuat atau bahkan menolak teori atau hipotesis hasil penelitian yang sudah ada sebelumnya.

Lokasi penelitian adalah Kantor Badan Pemeriksa Keuangan Perwakilan Provinsi Sulawesi Utara. Penelitian ini dilakukan pada bulan November 2017 sampai dengan bulan Januari 2018. Populasi dalam penelitian adalah seluruh auditor Badan Pemeriksa Keuangan Perwakilan Provinsi Sulawesi Utara yang berjumlah 63 orang. Teknik pengambilan sampel didasarkan pada teknik sensus, yaitu semua auditor (anggota populasi) dijadikan sebagai sampel penelitian.

Instrumen pengumpulan data pada penelitian ini adalah kuesioner (angket) yang berisi seperangkat pernyataan tertulis yang diberikan kepada responden untuk dinilai atau dijawab, dimana item-itemnya dijabarkan dari indikator-indikator variabel seperti pada Tabel 3.1. Selanjutnya skala pengukuran pada penelitian ini menggunakan skala Likert, dengan penilaiannya menggunakan sistem item favorable 5 poin, yaitu penilaian 5 ke 1 dan mempunyai gradasi dari sangat positif ke sangat negatif.

Teknik analisis data pada penelitian ini dengan pendekatan analisis kuantitatif, yaitu statistika deskriptif dan statistika inferensial menggunakan metode analisis SEM-PLS (Structural Equation Modeling-Partial Least Squares) dengan menggunakan software WarpPLS versi 6, dalam penerapan metode analisis ini tidak membutuhkan ukuran sampel yang besar (Sarwono, 2012).

\section{Hasil dan Pembahasan}

Sebelum dilakukan interpretasi terhadap hasil pengujian hipotesis, dilakukan pengujian validitas dan reliabilitas terlebih dahulu dimana nilai standar ukuran kebaikan atau rule of thumb mengacu pada pendapat Solimun et al (2017). Pada pengujian validitas diskriminan nilai muatan faktor (factor loading) dari hasil perhitungan berada pada $>0,5$. Rule of thumb yang digunakan dalam hal ini adalah jika nilai muatan faktor lebih besar sama dengan 0,5 dianggap cukup sebagai kriteria terpenuhinya validitas konvergen. Sedangkan untuk pengujian validitas diskriminan, nilai loading 
setiap indikator pada setiap variabel lebih besar dibandingkan dengan nilai cross-loading pada variabel laten lainnya, sehingga dapat dikatakan memenuhi sifat valid diskriminan. Pada pengujian reliabilitas, instrumen kuesioner dikatakan reliabel karena memiliki nilai cornbach's alpha $>0,6$ dan composite reliability $\geq 0,70$.

Pada analisis WarpPLS goodness of fit model diistilahkan dengan sebutan model fit and quality indices dimana indeks dan ukuran kebaikan hubungan antar variabel laten (inner model) dapat diketahui. Kriteria yang digunakan yang bersifat rule of thumb merujuk pada kriteria fit dari Kock (2017). Adapun hasil analisis seperti pada Tabel. 1 menunjukkan bahwa model fit and quality indices dari penelitian ini sudah baik dan ideal.

Tabel 1. Model Fit and Quality Indices

\begin{tabular}{|l|l|c|c|}
\hline \multicolumn{1}{|c|}{ Model Fit and Quality Indices } & \multicolumn{1}{|c|}{ Kriteria Fit } & Hasil Analisis & Ket. \\
\hline Average path coefficient (APC) & $\mathrm{p}<0,05$ & $\begin{array}{c}0,337 \\
(\mathrm{p}<0,001)\end{array}$ & Baik \\
\hline Average -squared (ARS) & $\mathrm{p}<0,05$ & $\begin{array}{c}0,751 \\
(\mathrm{p}<0,001)\end{array}$ & Baik \\
\hline Average adjusted $R$-squared (AARS) & $\mathrm{p}<0,05$ & Baik \\
\hline Average block VIF (AVIF) & $\begin{array}{l}\text { Acceptable if } \leq 5, \\
\text { ideally } \leq 3,3\end{array}$ & 1,863 & Ideal \\
\hline Average full collinearity VIF (AFVIF) & $\begin{array}{l}\text { Acceptable if } \leq 5, \\
\text { ideally } \leq 3,3\end{array}$ & 2,571 & Ideal \\
\hline Tenenhaus GoF (GoF) & $\begin{array}{l}\text { Small } \geq 0,1, \\
\text { medium } \geq 0,25, \\
\text { large } \geq 0,36\end{array}$ & 0,629 & Ideal \\
\hline Sympson's paradox ratio (SPR) & $\begin{array}{l}\text { Acceptable if } \geq 0,7, \\
\text { ideally }=1\end{array}$ & 1,000 & Ideal \\
\hline R-squared contribution ratio (RSCR) & $\begin{array}{l}\text { Acceptable if } \geq 0,9, \\
\text { ideally }=1\end{array}$ & 1,000 & Ideal \\
\hline Statistical suppression ratio (SSR) & Acceptable if $\geq 0,7$ & 1,000 & Ideal \\
\hline $\begin{array}{l}\text { Nonlinear bivariate causality direction ratio } \\
\text { (NLBCDR) }\end{array}$ & Acceptable if $\geq 0,7$ & 1,000 & Ideal \\
\hline
\end{tabular}

Sumber: Data Diolah, 2018

Pengujian terhadap hipotesis yang diajukan dalam penelitian ini dilakukan dengan metode analisis SEM-PLS (Structural Equation Modeling-Partial Least Squares) dengan menggunakan software WarpPLS. Output hasil perhitungan dari pengujian hipotesis bisa dilihat dari Tabel. 2 di bawah ini:

Tabel 2. Hasil Pengujian Hipotesis

\begin{tabular}{|c|c|c|c|c|c|c|}
\hline $\begin{array}{l}\text { Variabel } \\
\text { Eksogen }\end{array}$ & $\begin{array}{l}\text { Variabel } \\
\text { Endogen }\end{array}$ & $\begin{array}{c}\text { Koefisien } \\
\text { Jalur ( } \beta \text { ) }\end{array}$ & $\begin{array}{c}p- \\
\text { value }\end{array}$ & $\begin{array}{c}\text { Koefisien } \\
\text { Determinasi } \\
\left(R^{2}\right)\end{array}$ & $\begin{array}{l}\text { Effect } \\
\text { size }\end{array}$ & Ket. \\
\hline $\begin{array}{l}\text { Independensi } \\
\qquad\left(X_{1}\right)\end{array}$ & \multirow{3}{*}{$\begin{array}{l}\text { Kinerja } \\
(Y)\end{array}$} & 0,08 & 0,25 & \multirow{3}{*}{0,75} & 0,031 & $\begin{array}{c}\text { Berpengaruh } \\
\text { positif (tidak } \\
\text { signifikan) }\end{array}$ \\
\hline $\begin{array}{l}\text { Profesionalisme } \\
\qquad\left(X_{2}\right)\end{array}$ & & 0,05 & 0,33 & & 0,026 & $\begin{array}{l}\text { Berpengaruh } \\
\text { positif (tidak } \\
\text { signifikan) }\end{array}$ \\
\hline $\begin{array}{c}\text { Role Stress } \\
\left(\mathrm{X}_{3}\right)\end{array}$ & & $-0,87$ & $<0,01$ & & 0,693 & $\begin{array}{c}\text { Berpengaruh } \\
\text { negatif (signifikan) }\end{array}$ \\
\hline
\end{tabular}

Sumber: Data Diolah, 2018 
Dari hasil perhitungan terungkap bahwa, 4 hipotesis penelitian yang diajukan seluruhnya dapat diterima, hal ini bisa terlihat dari bobot nilai koefisien jalur, $p$-value, koefisien determinasi dan effect size, yang menjelaskan pengaruh antara variabel eksogen (independensi, profesionalisme dan role stress) terhadap variabel endogen (kinerja). Selanjutnya pada tabel 2 disajikan data-data hasil analisis pada masing-masing variabel

Variabel independensi memiliki pengaruh positif terhadap kinerja dengan nilai koefisien jalur $0,08, p$-value 0,25 dan effect size 0,031 . Untuk variabel profesionalisme memiliki pengaruh positif terhadap kinerja dengan nilai koefisien jalur 0,05 , p-value 0,33 dan effect size 0,026 . Nilai p-value pada variabel independensi dan profesionalisme berada pada angka $>0,05$ sehingga dikatakan tidak signifikan, hal ini dapat terjadi karena jumlah sampel dalam penelitian ini tergolong kecil, menurut Sarwono (2012) penggunaan sampel kecil kadang menghasilkan perhitungan statistik yang tidak signifikan karena sampel yang kecil kurang merepresentasikan hubungan antar variabel dalam penelitian. Namun jika melihat pada nilai effect size yang didapatkan dari perhitungan variabel independensi terhadap kinerja dan variabel profesionalisme terhadap kinerja yaitu berada pada angka $>0,02$ maka masing-masing variabel independensi dan profesionalisme dapat dikatakan berpengaruh terhadap kinerja, mengacu pada pendapat Jacob Cohen (1988) dalam Sholihin (2013) yang mengatakan bahwa effect size pada angka >0,02 telah menunjukkan adanya pengaruh variabel laten prediktor (eksogen/bebas) terhadap variabel kriterion (endogen/terikat). Selanjutnya untuk variabel role stress memiliki pengaruh negatif terhadap kinerja dengan nilai koefisien jalur - $0,87, p$-value $<0,01$ yang berarti signifikan dengan effect size sebesar 0,693.

Untuk pengaruh gabungan (simultan) merujuk pada pendapat Sarwono (2012), bahwa nilai koefisien determinasi $\left(\mathrm{R}^{2}\right)$ digunakan sebagai besaran nilai untuk mengekspresikan besarnya jumlah pengaruh semua variabel eksogenus terhadap variabel endogenus secara gabungan atau disebut sebagai pengaruh gabungan, jika nilai semakin mendekati 1 maka semakin besar pengaruh yang ada, dimana dalam hal ini koefisien determinasi yang didapatkan yaitu 0,75 sehingga menunjukkan adanya pengaruh gabungan antara variabel independensi, profesionalisme dan role stress terhadap variabel kinerja.

\section{Pengaruh Independensi Terhadap Kinerja}

Berdasarkan pengujian hipotesis diperoleh hasil bahwa independensi berpengaruh positif terhadap kinerja. Artinya, semakin baik level independensi dari auditor maka semakin meningkat pula kinerja dari auditor. Dengan demikian, hipotesis 1 yaitu terdapat pengaruh independensi terhadap kinerja auditor diterima.

Hasil penelitian ini menjelaskan bahwa semakin baik independensi auditor dalam hal ini dipandang dari dimensi pertama, independence in fact yaitu kemampuan auditor untuk menghindari konflik kepentingan dalam proses perencanaan, pelaksanaan dan pelaporan hasil audit, bebas dari campur tangan dari pihak entitas (klien), kemudian posisi dari auditor yang tidak memiliki hubungan baik secara kekeluargaan, hubungan bisnis dan lainnya, yang kedua dari dimensi independence in appearance yaitu bebas dari campur tangan pihak manapun dalam melakukan perumusan dan menyatakan pendapat terhadap objek audit, bentuk pelaporan yang menghindari bahasa dan istilahistilah yang ambigu baik secara sengaja maupun tidak, kemudian ketidakterlibatan auditor dalam urusan atau pekerjaan lain yang dapat menimbulkan kecurigaan (pertentangan) dengan tugas dan profesi auditor, akan mengakibatkan pencapaian kinerja auditor semakin tinggi.

Secara umum tingkat independensi auditor di BPK RI Perwakilan Sulawesi Utara sudah sangat baik bila diukur dari dimensi independence in fact dan dimensi independence in appearance. Untuk indikator yang berhubungan dengan adanya campur tangan pihak entitas dalam menjalankan prosedur audit memiliki bobot nilai yang paling tinggi artinya bahwa dalam proses pemeriksaan, auditor telah bebas dari intervensi pihak entitas atau instansi yang diperiksa, hal ini telah sesuai dengan Kode Etik yang ada yang menyebutkan bahwa independensi adalah suatu sikap dan tindakan dalam melaksanakan pemeriksaan untuk tidak memihak kepada siapapun dan tidak dipengaruhi oleh siapapun. Selanjutnya untuk indikator yang memiliki bobot nilai terendah berhubungan dengan teknis pelaporan dimana penyajian pelaporan masih terdapat kemungkinan munculnya bahasa atau istilahistilah yang ambigu, baik secara sengaja atau tidak dalam pelaporan fakta-fakta, pendapat, rekomendasi serta dalam penafsirannya.

Hasil penelitian ini sejalan dengan pendapat De Angelo (1981) yang menegaskan hubungan antara independensi auditor dan kinerja auditor, bahwa kemungkinan dimana auditor akan melaporkan salah saji tergantung pada kualitas independensi auditor. Secara empiris, penelitian ini mendukung 
hasil penelitian dari Arumsari et al. (2016) bahwa independensi auditor berpengaruh terhadap kinerja auditor.

\section{Pengaruh Profesionalisme Terhadap Kinerja}

Berdasarkan pengujian hipotesis diperoleh hasil bahwa profesionalisme berpengaruh positif terhadap kinerja. Artinya, semakin baik profesionalisme dari auditor maka semakin meningkat pula kinerja dari auditor. Dengan demikian, hipotesis 2 yaitu terdapat pengaruh profesionalisme terhadap kinerja auditor diterima.

Hasil penelitian ini menegaskan bahwa semakin baik derajat profesionalitas auditor dipandang dari sisi kompetensi dan pengendalian mutu yaitu auditor memiliki keahlian dan kemampuan dalam menjalankan tugas dan fungsi pemeriksa, auditor mendapatkan kesempatan untuk memperoleh pendidikan dalam rangka meningkatkan keahlian dan kemampuan dalam menjalankan tugas dan fungsi pemeriksa, juga dalam hal auditor menjadikan kode etik sebagai nilai-nilai utama yang selalu dijadikan acuan dalam pemeriksaan, selanjutnya dari sisi komitmen dan kehati-hatian yaitu auditor selalu melakukan evaluasi mutu dan kualitas terhadap hasil pemeriksaan, auditor selalu menggunakan prinsip kehati-hatian (due care), ketelitian dan kecermatan dan selalu berpedoman pada standar dan peraturan, kemudian memiliki komunikasi yang baik dalam menjalankan prosedur pemeriksaan, akan mengakibatkan pencapaian kinerja auditor semakin meningkat.

Secara umum tingkat profesionalitas auditor di BPK RI Perwakilan Sulawesi Utara sangat baik bila diukur dari dimensi kompetensi dan pengendalian mutu dan dimensi komitmen dan kehatihatian. Dalam hal ini nilai paling tinggi ada pada indikator yang menyatakan bahwa kode etik dalam pemeriksaan adalah nilai-nilai utama yang selalu dijadikan acuan, artinya setiap auditor sudah dengan sadar memahami bahwa Kode Etik adalah norma-norma yang harus dipatuhi selama menjalankan tugas untuk menjaga martabat, kehormatan, citra, dan kredibilitas BPK. Selanjutnya nilai yang terendah ada pada indikator yang berhubungan dengan adanya kesempatan dari setiap auditor untuk memperoleh pendidikan atau pelatihan dalam rangka meningkatkan keahlian dan kemampuan dalam menjalankan tugas dan fungsi pemeriksa, artinya walaupun secara umum sudah baik namun terdapat isu dari perlunya penambahan frekuensi pelaksanaan program pendidikan dan pelatihan yang dalam hal ini diselenggarakan oleh Badan Pendidikan dan Pelatihan Pemeriksaan Keuangan Negara (Badiklat PKN) sebagai salah satu unsur pelaksana tugas penunjang di BPK.

Hasil penelitian ini sejalan dengan pendapat Guy et al. (2002) yang menjelaskan hubungan antara profesionalitas auditor dan kinerja auditor, bahwa dibutuhkan kompetensi dan pengalaman untuk dapat menyelesaikan pekerjaan-pekerjaan dalam auditing. Secara empiris, penelitian ini mendukung hasil penelitian dari Novatiani et al. (2014) dan Nugraha et al. (2015) bahwa profesionalisme auditor berpengaruh terhadap kinerja auditor.

\section{Pengaruh Role Stress Terhadap Kinerja}

Berdasarkan pengujian hipotesis diperoleh hasil bahwa role stress atau tekanan peran berpengaruh negatif terhadap kinerja. Artinya, semakin tinggi tingkat stress dari auditor maka semakin menurun kinerja dari auditor, atau tingkat stress berbanding terbalik dengan pencapaian kinerja. Dengan demikian, hipotesis 3 yaitu terdapat pegaruh role stress terhadap kinerja auditor diterima.

Hasil penelitian ini sesuai dengan pendapat Fanani et al. (2008) yang mengatakan, konflik peran dapat menimbulkan rasa tidak nyaman dalam bekerja dan bisa menurunkan motivasi kerja karena mempunyai dampak negatif terhadap perilaku individu sehingga bisa menurunkan kinerja auditor secara keseluruhan. Dalam hal ini tingkat stress auditor jika dilihat dari dimensi role conflict (konflik peran) sebagai pemicunya yaitu terkait kenyamanan auditor terhadap profesinya, rincian tugas yang tidak bertentangan dengan nilai-nilai agama dan budaya, kemampuan auditor dalam menghindari stress dalam pekerjaan pemeriksaan, adanya konsistensi dalam rincian tugas, mengetahui apa harapan orang lain kepada diri sendiri, memperoleh kompensasi yang sesuai, tidak sedang dalam merangkap pekerjaan, memiliki fokus dalam menyelesaikan tugas dan tanggung jawab serta mengetahui cara membagi waktu dalam penyelesaian tugas pemeriksaan.

Hasil penelitian ini juga menjelaskan pengaruh dari role stress yang ada pada auditor yang dilihat dari dimensi role ambiguity (ketidakjelasan peran) yaitu terkait dengan pemahaman yang jelas terhadap job description, pemahaman yang jelas tentang hak dan kewajiban, kejelasan akan rencana dan tujuan pada saat tugas pemeriksaan, wewenang dalam menjalankan tugas, juga dukungan sumber daya baik material maupun orang dalam melakukan tugas pemeriksaan. 
Secara umum tingkat stress auditor di BPK RI Perwakilan Sulawesi Utara tergolong rendah bila diukur dari dimensi role conflict dan dimensi role ambiguity. Dalam hal ini nilai paling rendah berada pada indikator yang menyebutkan bahwa rincian tugas dan profesi sebagai auditor bertentangan dengan nilai-nilai agama dan budaya, artinya bahwa setiap auditor meyakini bahwa tugas dan fungsi sebagai auditor baik secara aturan dan tata cara tidak pernah bertentangan dengan nilai-nilai dan ajaran dari agama dan kultur yang dipercaya. Selanjutnya indikator yang memiliki nilai paling tinggi atau yang paling memiliki potensi sebagai pemicu stress ada pada hal yang berhubungan dengan pelaksanaan penugasan yang tidak didukung dengan jumlah tenaga kerja (sumber daya manusia) yang cukup, faktanya memang perbandingan antara jumlah entitas yang diperiksa dengan jumlah auditor masih belum ideal, menurut Ketua BPK Harry Azhar Azis, jumlah auditor yang dimiliki masih sangat belum memadai, sehingga perlu adanya keleluasaan dari Kementrian Pendayagunaan Aparatur Negara dan Reformasi Birokrasi (KemenPAN-RB) dalam perekrutan pegawai, idealnya dibutuhkan 5 auditor per kabupaten/kota dan 9 auditor per provinsi, tapi sekarang hanya 4 (antaranews.com, 2015). Untuk daerah Sulawesi Utara sendiri yang terdapat 15 kabupaten/kota dan 1 provinsi, auditor yang dimiliki Perwakilan Sulawesi Utara hanya berjumlah 50 orang yang berada pada level pelaksana, sehingga masih jauh dari ideal, padahal perhitungan belum termasuk pada entitas BUMD dan lembaga lain yang ada di Sulawesi Utara.

Hasil dari penelitian ini sejalan dengan teori peran dari Kahn et al. (1964) yang mengatakan bahwa, role stress yang berkepanjangan dapat memupuk ketidakpuasan kerja, mengikis kepercayaan diri, dan menghambat kinerja. Secara empiris, hasil penelitian ini sesuai dengan studi yang dilakukan Rahmawati (2012) bahwa konflik peran dan ketidakjelasan peran berpengaruh terhadap kinerja auditor.

\section{Pengaruh Independensi, Profesionalisme dan Role Stress Terhadap Kinerja}

Berdasarkan pengujian hipotesis diperoleh hasil bahwa independensi, profesionalisme dan role stress secara bersama-sama (simultan) berpengaruh terhadap kinerja. Dengan demikian, hipotesis 4 yaitu terdapat pengaruh independensi, profesionalisme dan role stress terhadap kinerja auditor diterima.

Dimensi kinerja auditor diukur dari pertama mutu, yaitu kemampuan auditor untuk menyelesaikan banyak pekerjaan dibandingkan rekan lain, auditor selalu menemukan cara untuk meningkatkan kualitas pemeriksaannya, selalu memberikan usulan konstruktif terkait pekerjaan pemeriksaan, kemudian dari dimensi penghargaan yaitu hasil pekerjaan selalu dinilai sangat bagus, usulan yang selalu diapresiasi, self appraisal terhadap kinerja sendiri yang baik, selanjutnya dari dimensi hubungan baik yaitu selalu berpartisipasi aktif dalam pertemuan dengan rekan seprofesi, memiliki dan mempertahankan komunikasi yang baik dengan entitas (klien) pada masa penugasan dan setelahnya. Ukuran kinerja dalam penelitian ini menggunakan metode self appraisal, merujuk pada pendapat Kalbers et al. (1995) yang mengatakan bahwa evaluasi kinerja auditor dapat dilakukan oleh atasan, rekan kerja, diri sendiri (self appraisal) dan bawahan langsung.

Hasil penelitian ini sejalan dengan pendapat De Angelo (1981) bahwa kemungkinan dimana auditor akan menemukan salah saji tergantung pada kualitas pemahaman auditor (kompetensi) yang dalam penelitian ini diukur lewat variabel profesionalisme, sementara tindakan melaporkan salah saji tergantung pada independensi auditor. Dengan demikian kompetensi dan kualitas auditor (profesionalisme) sangat mempengaruhi independensi seorang auditor. Hasil penelitian ini pun sejalan dengan studi empiris yang dilakukan Tjun Tjun et al. (2012) bahwa independensi dan kompetensi secara simultan berpegaruh terhadap kualitas audit dan juga hasil studi dari Putra et al. (2012) yang menemukan bahwa independensi, profesionalisme dan role stress secara bersama-sama berpengaruh terhadap kinerja auditor.

\section{Penutup}

Berdasarkan hasil analisis dan pembahasan dalam penelitian ini dapatlah disimpulkan beberapa hal sebagai berikut: (1) Independensi berpengaruh positif terhadap kinerja auditor. Artinya, semakin baik level independensi dari auditor maka semakin meningkat pula kinerja dari auditor; (2) Profesionalisme berpengaruh positif terhadap kinerja auditor. Artinya, semakin baik profesionalisme dari auditor maka semakin meningkat pula kinerja dari auditor; (3) Role stress berpengaruh negatif terhadap kinerja auditor. Artinya, semakin tinggi tingkat stress dari auditor maka semakin menurun kinerja dari auditor; (4) Independensi, profesionalisme dan role stress secara simultan berpengaruh terhadap kinerja auditor. 
Saran untuk BPK RI Perwakilan Provinsi Sulawesi Utara: (1) Independensi yang dipandang dari sisi independence in fact dan independence in appearance memiliki dampak positif terhadap kinerja dari auditor, maka diharapkan pimpinan BPK terus mempertahankan dan meningkatkan level independensi dari para auditornya lewat aturan dan kebijakan yang dibuat; (2) Profesionalisme memiliki peran positif dalam terwujudnya kinerja auditor yang lebih baik, untuk itu pimpinan BPK perlu untuk menciptakan program dan kesempatan yang lebih banyak bagi para auditornya untuk memperoleh pendidikan dalam rangka meningkatkan keahlian dan kemampuan dalam menjalankan tugas dan fungsi pemeriksa; (3) Role stress adalah merupakan faktor dominan yang mempengaruhi kinerja dari auditor, secara umum memang tingkat stress yang ada pada auditor BPK khususnya pada Perwakilan Provinsi Sulawesi Utara berada pada level rendah, sehingga bisa dikatakan sistem yang ada sudah mampu menekan tingkat stress dari para auditor. Namun yang perlu diperhatikan adalah adanya indikasi dari masih kurangnya jumlah auditor yang ada, sehingga dukungan SDM masih dikatakan kurang, hal ini merupakan indikator yang paling kuat yang menjadi penyebab meningkatnya tingkat stress dari auditor; (4) Independensi, profesionalisme dan role stress berperan penting dalam terwujudnya kinerja auditor yang lebih baik, maka hendaknya pimpinan BPK selalu dapat mempertimbangkan faktor-faktor ini dalam setiap perumusan dan penentuan strategi serta kebijakan kelembagaan dalam setiap proses pemeriksaan yang dilakukan.

Saran untuk penelitian yang akan datang, hasil temuan ini perlu diuji lagi melalui penelitian dengan menggunakan konstruksi model penelitian yang sama dengan penelitian ini tetapi mengambil obyek penelitian yang lain atau obyek penelitian yang sama tapi lebih diperluas. Kemudian untuk penelitian yang akan datang dapat dilakukan dengan konstruksi model yang ditambahkan variabel mediasi sebagai variabel perantara pada variabel eksogen ataupun variabel endogen yang mempengaruhi kinerja auditor. Selain itu penelitian diwaktu yang akan datang juga bisa dilakukan dengan pendekatan kualitatif supaya dapat memperkaya khazanah ilmu pengetahuan.

\section{Daftar Pustaka}

Amilin dan Rosita Dewi. 2008. Pengaruh Komitmen Organisasi terhadap Kepuasan Kerja Akuntan Publik dengan Role Stress sebagai Variabel Moderating. Jurnal Akuntansi \& Auditing Indonesia, Vol 12 No. 1 Juni Fakultas Ekonomi dan Ilmu Sosial UIN Syarif Hidayatullah: Jakarta.

Armando, Ade. 2012. Mengenal Lebih Dekat BPK. Biro Humas dan Luar Negeri BPK RI: Jakarta

Arumsari, Adelia dan I Ketut Budiartha. 2016. Pengaruh Profesionalisme Auditor, Independensi Auditor, Etika Profesi, Budaya Organisasi, dan Gaya Kepemimpinan Terhadap Kinerja Auditor Pada Kantor Akuntan Publik di Bali. E-Jurnal Ekonomi dan Bisnis Vol.5 No.8. FEB Universitas Udayana: Bali.

Assegaf, Yasmin Umar. 2005. Pengaruh Konflik Peran dan Stress Kerja Terhadap Komitmen Organisasi. Jurnal Akuntansi dan Bisnis Vol 5 No.2 Agustus. 2005. UNS: Surakarta

Awaludin, Murtiadi. 2013. Pengaruh Independensi dan Kompetensi Auditor Terhadap Kepuasan Kerja Dan Kinerja Auditor Inspektorat Kota Makassar. Jurnal, Ekonomi, Manajemen dan Akuntansi Vol 3 No. 2 Desember. UINA: Makassar

BPK RI. 2016. Warta BPK Edisi 01 Vol VI. Sekjen BPK RI: Jakarta.

De Angelo, L.E. 1981. Auditor Independence, Low Balling, and Disclosure Regulation. Journal of Accounting and Economics. 3, 183-199.

Fanani, Zaenal Rheny Afriana Hanif, dan Bambang Subroto. 2008. Pengaruh Struktur Audit, Konflik Peran, dan Ketidakjelasan Peran Terhadap Kinerja Auditor. Jumal Akuntansi dan Keuangan Indonesia Volume 5 - Nomor 2

Guy, D. M., Alderman, C. Wayne dan Winters, Alan J. 2002. Auditing: Jilid 1. Jakarta: Erlangga.

Kahn, R.L, Wolfe, D.M, Quin, R,Snoek, J,D dan Rosenthal, R.A. 1964. Organizational stress: Studies in role confict and ambiguitas. New York: Wiley.

Kalbers, Lawrence P., dan Fogarty, Timothy J. 1995. Professionalism Its Consequences: A Study of Internal Auditors. Auditing: A Journal of Practice. Vol. 14. No. 1.

Kock, Ned. 2017. WarpPLS User Manual: Version 6.0. ScriptWarp Systems: Texas, USA.

Koo, Chi Mo and Ho Seog Sim. 1997. On the Role Conflict of Auditors in Korea. Accounting, Auditing, \& Accountability Journal, Vol 12 No.2 pp. 206-219, MCB University Press.

Novatiani, R. Ait \& Taofik Mustofa. 2014. Pengaruh Profesionalisme Auditor Internal Dan Komitmen Organisasi Auditor Internal Terhadap Kinerja Auditor Internal (Studi Kasus Pada Inspektorat 
Kabupaten Purwakarta). Conference on Management and Behavioral Studies (CMBS) 2014. FE Universitas Widyatama: Bandung.

Nugraha, Ida Bagus dan I Wayan Ramantha. 2015. Pengaruh Profesionalisme, Etika Profesi dan Pelatihan Auditor Terhadap Kinerja Auditor Pada Kantor Akuntan Publik di Bali. E-Jurnal Akuntansi Universitas Udayana, Vol 13.3 Desember.

Oktavia, Ika. 2015. Pengaruh Independensi Auditor, Profesionalisme, Dan Etika Profesi Terhadap Kinerja Auditor Eksternal Pada Kantor Akuntan Publik Di Wilayah Jakarta Timur. FE Universitas Dharma Persada: Jakarta.

Putra, I Gede Bandar dan Dodik Ariyanto. 2012. Pengaruh Independensi, Profesionalisme, Struktur Audit, dan Role Stress Terhadap Kinerja Auditor BPK RI Perwakilan Provinsi Bali. Jurnal Akuntansi. Vol 1 No 1 November. Universitas Udayana: Bali.

Rahmawati. 2012. Pengaruh Role Stress Terhadap Kinerja Auditor Dengan Emotional Quotient Sebagai Variabel Moderating. FEB UIN Syarif Hidayatullah: Jakarta.

Sarwono, Jonathan. 2012. Path Analysis Untuk Riset Skripsi, Tesis dan Disertasi. Elex Media Komputindo: Kompas Gramedia Jakarta.

Sholihin, Mahmud, Dwi Ratmono. 2013. Analisis SEM-PLS dengan WarpPLS Untuk Hubungan Nonlinier dalam Penelitian Sosial dan Bisnis. Penerbit ANDI: Yogyakarta.

Solimun, Adji A. R. Fernandes, Nurjannah. 2017. Pemodelan Persamaan Struktural (SEM) Pendekatan WarpPLS. UB Press: Malang.

Tjun Tjun, Lauw, Elyzabet Marpaung dan Santy Setiawan. 2012. Pengaruh Kompetensi dan Independensi Auditor Terhadap Kualitas audit. Jurnal Akuntansi, Vol 4 No.1 Mei.

Antaranews.com.2015.

https://www.antaranews.com/berita/527276/bpk-jumlah-auditor-sangat-belum-memadai (Akses 20 Oktober 2017)

Kompas.com.2017.

https://nasional.kompas.com/read/2017/05/27/14054551/icw.sejak.2005.ada.6.kasus.suap. libatkan.23.pejabat.bpk (Akses 20 Oktober 2017) 